\title{
Internasjonal helse og global helse - hva er forskjellen?
}

\author{
De siste 15-20 årene har begrepet global helse i stor grad overtatt for internasjonal helse. Dette gjenspeiler \\ behovet for å beskrive verdens helseutfordringer i lys av samfunnsstrukturer og overnasjonale politiske \\ beslutninger.
}

Internasjonal helse og global helse er to begreper som ofte brukes om hverandre (1). Internasjonal helse har tradisjonelt vært brukt for å beskrive sykdommer og helsearbeid som er av særlig stor betydning i lavog mellominntektsland, slik som infeksjonssykdommer, tropesykdommer, underernæring og barne- og mødrehelse (2). Tropemedisin er smalere begrep som er knyttet til tropiske sykdommer. Begrepet global helse har vært vanskeligere å definere og er blitt belyst $i$ en rekke artikler (2-5).

Et fellestrekk ved alle foreslåtte definisjoner av global helse er at verdens utfordringer innen helse vurderes å ha underliggende årsaker som gjelder for alle land (2-5). Mens internasjonal helse i stor grad belyser helseutfordringer i «andre land», sett fra perspektivet til høyinntektsland, legger global helse mer vekt på faktorer som ikke er begrenset til geografiske områder. Ulikheter i inntekt, utdanningsnivå og tilgang til kunnskap, boforhold, arbeidsforhold eller etnisk bakgrunn, såkalte sosiale helsedeterminanter, er relevante for alle land (6). Helse påvirkes av handelsavtaler, teknologisk utvikling, finanssystemer og økt flyt av varer, kapital, kunnskap og mennesker (7). Strenge patentlover reduserer tilgangen på viktige medisiner mot sykdommer som hiv/aids og hepatitt $\mathrm{C}$, som har høy forekomst i lavinntektsland. Kort sagt: helse er knyttet til politikk (8). Klimaendringene og utvikling av antibiotikaresistens er andre eksempler på utfordringer som ikke er begrenset til bestemte geografiske områder.

\section{Nye internasjonale \\ samarbeidsformer}

Mens internasjonal helse i stor grad er et deskriptivt begrep, har global helse et mer analytisk fokus som også peker på mulige løsninger. Skiftet fra internasjonal helse til global helse gjenspeiler nye internasjonale samarbeidsformer, bl.a. den globale vaksinealliansen GAVI og det filantropiske arbeidet til Bill og Melinda Gates Foundation.

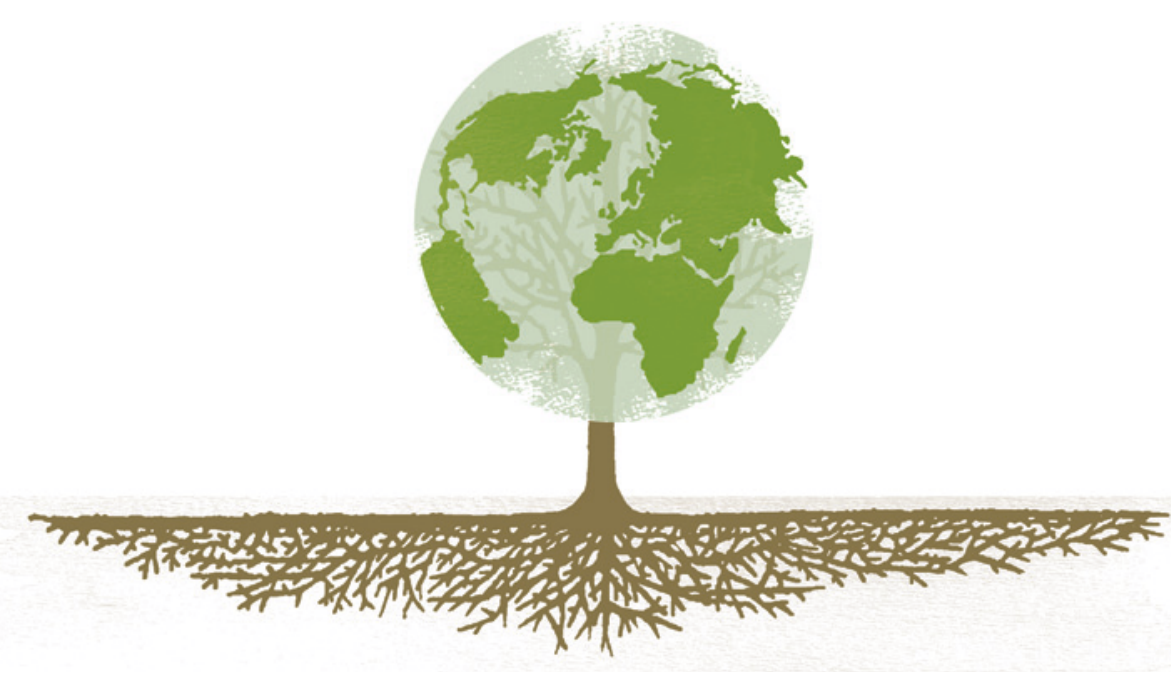

Illustrasjon (c) Superpop

Det gjenspeiler også behovet for globale strukturelle tiltak, som regulering av markedsføring av tobakk og usunne matvarer og utvikling av et nytt innovasjonssystem for medisiner for neglisjerte tropiske sykdommer (9). Dette arbeidet krever bevisste politiske valg som må veie hensynet til helse mot andre, ofte økonomiske, interesser som forsvares av transnasjonale selskaper eller mektige stater. Begrepet global helse vil fylles med ulikt innhold, og uenigheten om definisjonen vil nok vedvare.

\section{Unni Gopinathan}

unni.gnathan@gmail.com

Unni Gopinathan (f. 1986) er turnuslege ved Akershus universitetssykehus og doktorgradsstipendiat ved Avdeling for medisinsk biokjemi, Oslo universitetssykehus.

\section{Litteratur}

1. Stoltenberg C. Global helse. Store Norske Leksikon. http://sml.snl.no/global helse (22.8.2014).

2. Koplan JP, Bond TC, Merson MH et al. Towards a common definition of global health. Lancet 2009 373: $1993-5$.
3. Fried LP, Bentley ME, Buekens $P$ et al. Global health is public health. Lancet 2010; 375: 535-7. 4 Beaglehole R, Bonita R. What is global health? Glob Health Action 2010; 3.

5. Bozorgmehr K. Rethinking the 'global' in global health: a dialectic approach. Global Health 2010; 6: 19 .

6. Commission on Social Determinants of Health. Closing the gap in a generation: health equity through action on the social determinants of health: Commission on Social Determinants of Health final report. Genève: World Health Organization, 2008: 246.

7. Labonté R, Mohindra K, Schrecker T. The growing impact of globalization for health and public health practice. Annu Rev Public Health 2011; 32: 263-83.

8. Ottersen OP, Dasgupta J, Blouin C et al. The political origins of health inequity: prospects for change. Lancet 2014: 383: 630-67.

9. Røttingen J-A, Chamas C. A new deal for global health R\&D? The recommendations of the Consultative Expert Working Group on Research and Development (CEWG). PLoS Med 2012; 9: e1001219.

Mottatt 29.4. 2014, første revisjon innsendt 18.8. 2014, godkjent 22.8. 2014. Redaktør: Marit Skaar Fjellhaug. 